\title{
THE G209A MUTATION IN THE $\alpha$-SYNUCLEIN GENE IN BRAZILIAN FAMILIES WITH PARKINSON'S DISEASE
}

\author{
Hélio A. G. Teive', Salmo Raskin², Fábio M. Iwamoto', Francisco M.B. Germiniani', \\ Maria H.H. Baran', Lineu C. Werneck', Nasser Allan³, Elizabeth Quagliato', \\ Elisabeth Leroy ${ }^{5}$, Susan E. Ide ${ }^{5}$, Mihael H. Polymeropoulos ${ }^{5}$
}

\begin{abstract}
A missense G209A mutation of the alpha-synuclein gene was recently described in a large Contursi kindred with Parkinson's disease (PD). The objective of this study is to determine if the mutation G209A of the alpha-synuclein gene was present in 10 Brazilian families with PD. PD patients were recruited from movement disorders clinics of Brazil. A family history with two or more affected in relatives was the inclusion criterion for this study. The alpha-synuclein G209A mutation assay was made using polymerase chain reaction and the restriction enzyme Tsp45I. Ten patients from 10 unrelated families were studied. The mean age of PD onset was 42.7 years old. We did not find the G209A mutation in our 10 families with PD. Our results suggest that alpha-synuclein mutation G209A is uncommon in Brazilian PD families.
\end{abstract}

KEY WORDS: Parkinson's disease, alpha-synuclein, genetics.

Mutação G209A no gene da alfa-sinucleína em famílias brasileiras com doença de Parkinson

RESUMO - Recentemente foi detectada mutação missense G209A no gene da alfa-sinucleína em uma grande família com doença de Parkinson (DP) de Contursi, Itália. Este estudo tem o objetivo de determinar se a mutação G209A está presente em 10 famílias brasileiras com DP. Pacientes com DP foram recrutados em clínicas de distúrbio do movimento no Brasil. 0 critério de inclusão no estudo foi à presença de dois ou mais familiares acometidos pela DP. A mutação G209A do gene da alfa-sinucleína foi pesquisada usando a técnica de reação em cadeia de polimerase e a enzima de restrição Tsp45I. Foram estudados 10 pacientes de famílias não-relacionadas. A idade média do início dos sintomas da DP foi 42,7 anos. Não encontramos a mutação estudada neste grupo de pacientes. Nossos resultados sugerem que a mutação G209A é incomum em famílias brasileiras com DP.

PALAVRAS-CHAVE: doença de Parkinson, alfa-sinucleína, genética molecular.

Parkinson's Disease (PD) is one of the most common neurodegenerative diseases and its diagnosis is based on the presence of at least two of its cardinal signs: bradikinesia, rigidity, resting tremor, and postural instability'. In 1997 Polymeropoulos et al. ${ }^{2}$ found a missense G209A mutation in the alpha-synuclein gene in a large family diagnosed with PD from Contursi, Italy and in another 3 Greek families with an autossomal dominant pattern. This point mutation leads to the substitution of alanine by treonine at the 53 position in the aminoacid sequence of the alpha-synuclein (Ala53Thr) ${ }^{1}$. Later, Kruger et al. ${ }^{3}$ described a second point mutation that leads to the substitution of alanine by proline at the 30 position in the aminoacid sequence. Nevertheless, mutations in the alpha-synuclein gene are a rare cause of PD in families from North America, ${ }^{4,5}$ Europe $^{6}$ and China ${ }^{7}$.

In Brazil there are no studies focusing on the mutations of the alpha-synuclein in families with PD and our study's objective is to determine whether the G209A mutation can be found among 10 Brazilian families with PD.

\section{METHOD}

Patients with PD from different Brazilian Movement Disorders study centers were enrolled for the study. Patients were included if there was at least one relative who had been also diagnosed with PD. We studied 10 index patients from 10 different, unrelated Brazilian families. In 4 families the inheritance pattern was clearly autossomal recessive (index-cases 1, 7, 8 and 10) and among the oth-

${ }^{1}$ Movement Disorders Unit, Neurological Service, Hospital de Clínicas, Federal University of Paraná, Curitiba PR, Brasil; ${ }^{2}$ Genetika- Centro de Aconselhamento e Laboratório de Genética, Curitiba PR, Brasil; ${ }^{3}$ Neurological Service, Hospital de Base, Brasília DF, Brasil; ${ }^{4}$ Neurological Department Unicamp, Campinas SP, Brasil; ${ }^{5}$ National Human Genome Research Institute, National Institute of Health, Bethesda, MD, USA.

Received 18 January 2001, received in final form 30 April 2001. Accepted 10 May 2001.

Dr. Hélio Teive - Serviço de Neurologia, Hospital de Clínicas da UFPR - Rua General Carneiro 181 - 80069-900 Curitiba PR - Brasil. FAX: 5541 264-3606. E-mail: hagteive@mps.com.br 
Table 1. Clinical features and family history of patients with $P D$.

\begin{tabular}{|c|c|c|c|c|c|c|}
\hline $\begin{array}{l}\text { Index } \\
\text { case }\end{array}$ & $\begin{array}{l}\text { Age and } \\
\text { gender }\end{array}$ & $\begin{array}{l}\text { Age of } \\
\text { onset }\end{array}$ & $\begin{array}{c}\text { Number of } \\
\text { affected relatives }\end{array}$ & $\begin{array}{l}\text { Relationship of } \\
\text { affected relatives }\end{array}$ & $\mathrm{H}-\mathrm{Y}$ & $\begin{array}{l}\text { Ethnic } \\
\text { background }\end{array}$ \\
\hline 1 & $64(F)$ & 58 & 4 & 4 sisters & 2,5 & Italian \\
\hline 2 & $66(M)$ & 56 & 2 & $\begin{array}{c}\text { Father } \\
\text { Paternal cousin }\end{array}$ & 2,5 & $\begin{array}{l}\text { Italian } \\
\text { Polish }\end{array}$ \\
\hline 3 & $46(\mathrm{M})$ & 38 & 4 & 4 Paternal uncles & 2 & Italian \\
\hline 4 & $67(M)$ & 65 & 2 & $\begin{array}{l}\text { Father } \\
\text { Sister }\end{array}$ & 2 & Portuguese \\
\hline 5 & $61(\mathrm{M})$ & 54 & 1 & Father & 3 & Brazilian \\
\hline 6 & $40(\mathrm{M})$ & 31 & 1 & Mother & 3 & $\begin{array}{l}\text { German } \\
\text { Italian }\end{array}$ \\
\hline 7 & $39(\mathrm{M})$ & 17 & 2 & 2 Brothers & 2,5 & Italian \\
\hline 8 & $67(M)$ & 55 & 2 & $\begin{array}{c}\text { Brother } \\
\text { Paternal aunt }\end{array}$ & 2 & Italian \\
\hline 9 & $43(\mathrm{M})$ & 42 & 1 & Maternal uncle & 1,5 & Italian \\
\hline 10 & $31(F)$ & 11 & 2 & $\begin{array}{c}\text { Sister } \\
\text { Maternal uncle }\end{array}$ & 5 & Brazilian \\
\hline
\end{tabular}

Age and age of onset in years. M, male; F, female; H-Y: Hoehn-Yahr scale.

ers a clear genetic transmission pattern could not be established. The mean age at onset of symptoms was 42.7 years of age, ranging from 11 to 65 years (Table 1).

DNA from the index cases was extracted from peripheral blood leukocytes at the Laboratório Genétika (Dr. Salmo Raskin). Genetic analysis was later performed at the National Human Genome Research Institute, National Institute of Health, Bethesda, MD, USA (Dr. Mihael Polymeropoulos), using previously described primers for DNA amplification through polimerase chain reaction. The G209A mutation of the alpha-synuclein gene was detected by using the Tsp451 restriction enzyme, as previously described $^{1}$.

\section{RESULTS}

We could not find the G209A mutation in the exon 4 of the alpha-synuclein gene in the families studied.

\section{DISCUSSION}

It has previously been established that a certain percentage of PD has a genetic origin, more so if onset of the disease is before 50 years of age. Mutations of the alpha-synuclein gene at $4 q$ chromosome (PARK1) were reported in families with autossomal dominant inheritance pattern from Italy, Greece and Germany ${ }^{2,3}$. Other two locirelated to autossomal do-

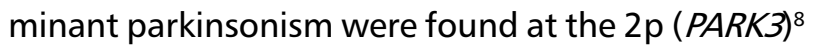
and at the $4 \mathrm{p}^{9}$ chromosomes. In addition, a missense mutation at the ubiquitine carboxi-terminal hydrolase L1 (UCH-L1) gene on chromosome $4 p$ was linked to parkinsonism in one family ${ }^{10}$. Mutations in another gene for parkinsonism on chromosome $6 q$, parkin (PARK2), were detected in families that had autossomal recessive juvenile parkinsonism ${ }^{11}$.

Patients with mutations of the alpha-synuclein gene present with early onset PD (mean age of onset of 46 years, whereas patients with sporadic PD have a mean age of onset of 59.7), a rather fast course from onset to death, a higher incidence of dementia and other signs non-related to parkinsonism (aphasia, myoclonus and palilalia) and a worse response to levodopa therapy than patients with classic PD. Brain pathology is the same in both classic PD and PD related to mutations of the alpha. The G209A mutation in the $\alpha$-synuclein gene is not detected in familial cases of Parkinson $\alpha$-synuclein gene, making them indistinguishable on a pathological basis. Both present with neuronal degeneration of the substantia nigra and Lewy bodies ${ }^{12,13}$.

Alpha-synuclein is a protein that can be found in great amounts in the brain, mainly at the medulla, olfactory tract, hypothalamus and the substantia nigra. Its exact function and its role in the pathogenesis of PD are still unclear. However, immunocytochemical studies have shown that the alpha-synuclein protein is an important component of the Lewy bodies, even in those cases of patients without mutations of the alpha-synuclein gene ${ }^{1}$.

In order to evaluate the prevalence of familiar PD linked to mutations of the alpha-synuclein gene, Gasser et al. studied 13 families with an autossomal dominant inheritance pattern and excluded, through linkage and sequencing studies, mutations of the 
Table 2. Negative results of the study of the synuclein gene mutations.

\begin{tabular}{|c|c|c|c|c|c|}
\hline Author & Country (ies) & $\begin{array}{l}\text { Number of } \\
\text { patients }\end{array}$ & $\begin{array}{l}\text { Familial or } \\
\text { sporadic }\end{array}$ & Tested mutation & Result \\
\hline Warner \& Schapira & UK & 70 & Sporadic & G209A & Negative \\
\hline Vaughan et al. & Europe & 230 & Familial & G209A & Negative \\
\hline Farrer et al. & USA/ Europe/ Asia & 11 & Familial & $\begin{array}{c}\text { G209A } \\
\text { Sequencing }\end{array}$ & Negative \\
\hline Ho et al. & China/UK & 127 & Sporadic & G209A & Negative \\
\hline Pasian et al. & USA & 216 & $\begin{array}{l}83 \mathrm{~F} \\
133 \mathrm{~S}\end{array}$ & $\begin{array}{c}\text { G209A } \\
\text { Sequencing }\end{array}$ & Negative \\
\hline Vaughan & $\begin{array}{l}\text { USA } \\
\text { Europe }\end{array}$ & 30 & $\begin{array}{l}\text { Familial } \\
\text { (AD) }\end{array}$ & Sequencing & Negative \\
\hline Chan et al. & USA & $\begin{array}{c}100 \text { cases } \\
\text { of early onset }\end{array}$ & $\begin{array}{l}83 \mathrm{~S} \\
17 \mathrm{~F}\end{array}$ & G209 & Negative \\
\hline Chan et al. & China & $\begin{array}{c}207 \text { cases } \\
\text { (17 early onset) }\end{array}$ & $\begin{array}{c}183 \mathrm{~S} \\
7 \mathrm{~F}\end{array}$ & $\begin{array}{c}\text { G209A } \\
\text { C88G }\end{array}$ & Negative \\
\hline Teive et al. & Brazil & $\begin{array}{c}31 \text { cases } \\
\text { (13 early onset) }\end{array}$ & Familial & G209A & Negative \\
\hline
\end{tabular}

USA, United States of America; UK, United Kingdom; S, sporadic; F, familial; AD, autossomal dominant.

alpha-synuclein gene ${ }^{14}$. Later studies with both familial and sporadic cases of PD, with and without early onset, in many countries of Europe, North America and Asia using different techniques for the detection of point mutations or genetic sequencing could not find any mutation of the alpha-synuclein gene (Table 2) (-7, 15-20 $^{-}$

In spite of the small size of our sample, our results suggest that the G209A mutation is uncommon among Brazilian families with PD, results similar to those found in other countries. Truthfully, in none of the studied families we could establish an autossomal dominant inheritance pattern.

Mutations at the other gene linked to PD, which is located in the $6 q$ chromosome (parkin), were first described in Japan ${ }^{11}$ and later in several other countries ${ }^{21}$. Mutations of the parkingene seemingly have a worldwide distribution, whereas alpha-synuclein mutations are restricted to a few European families. Further studies are still necessary to identify the gene or genes that play a role in the etiology of PD in these 10 Brazilian families.

\section{REFERENCES}

1. Polymeropoulos MH. Autosomal dominant Parkinson's disease and alpha-synuclein. Ann Neurol 1998; 44(Suppl 1):63-64.

2. Polymeropoulos $\mathrm{MH}$, Levadan $\mathrm{C}$, Leroy E, et al. Mutation in the alpha-synuclein gene identified in families with Parkinson's disease. Science 1997;276:2045-2047.

3. Krüger R, Kuhn W, Muller T, et al. Ala30Pro mutation in the gene encoding alpha-synuclein in Parkinson's disease. Nat Genet 1998;18:106-108.

4. Chan $P$, Tanner CM, Jiang $X$, Langston JW. Failure to find the alphasynuclein gene missense mutation (G209A) in 100 patients with younger onset Parkinson's disease. Neurology 1998;50:513-514.
5. Wang WW, Khajavi M, Patel BJ, Beach J, Jankovic J, Ashizawa T. The G209A mutation in the $\alpha$-synuclein gene is not detected in familial cases of Parkinson disease in non-Greek and/or Italian populations. Arch Neurol 1998;55:1521-1523.

6. Vaughan J, Durr A, Tassin J, Bereznai B, Gasser T, Bonifati V, et al. The $\alpha$-synuclein Ala53Thr mutation is not a common cause of familial Parkinson's disease: a study of 230 European cases. Ann Neurol 1998; 44:270-273.

7. Chan DKY, Mellich G, Cai H, et al. The $\alpha$-synuclein gene and Parkinson disease in a Chinese population. Arch Neurol 2000;57:501-503.

8. Gasser T, Müller-Myhsok B, Wszolek ZK, et al. A susceptibility locus for Parkinson's disease maps to chromosome 2p13. Nat Genet 1998;18:262-265.

9. Farrer M, Gwinn-Hardy K, Muenter M, et al. A chromosome 4p haplotype segregating with Parkinson's disease and postural tremor. Hum Mol Genet 1999; 8:81-85.

10. Leroy E, Boyer R, Auburger G, et al. The ubiquitin pathway in Parkinson's disease. Nature 1998;395:451-452.

11. Kitada T, Askawa S, Hattori N, et al. Mutations in the parkin gene cause autosomal recessive juvenile parkinsonism. Nature 1998;392:605-608.

12. Gasser T. Genetics of Parkinson's disease. Ann Neurol 1998;44(Suppl 1):53-57.

13. Golbe LI, Di Iorio G, Sanges G, Lazzarini AM, LaSala S, Bonavita V, et al. Clinical genetic analysis of Parkinson's disease in the Contursi kindred. Ann Neurol 1996;40:767-775.

14. Gasser T, Müller-Myhsok B, Wszolek ZK, et al. Genetic complexity and Parkinson's disease. Science 1997;277:388-389.

15. Bennet P, Nicholl DJ. Absence of G209A mutation in alpha-synuclein gene in British families with Parkinson's disease. Neurology 1998; 50:1183.

16. Ho SL, Kung MHW. G209A mutation in the $\alpha$-synuclein gene is rare and not associated with sporadic Parkinson's disease. Mov Disord 1998;13:970-971.

17. Parsian A, Racette B, Zhang ZH, et al. Mutation, sequence, analysis, and association of a-synuclein in Parkinson's disease. Neurology 1998;51:1757-1759.

18. Waner TT, Schapira AHV. The role of the a-synuclein gene mutation in patients with sporadic Parkinson's disease in the United Kingdom. J Neurol Neurosurg Psychiatry 1998;65:378-379.

19. Farrer M, Wavrant-De Vrieze F, Crook R, et al. Low frequency of asynuclein mutations in familial Parkinson's disease. Ann Neurol 1998:43:394-397.

20. Vaughan Jr, Farrer MJ, Wszolek ZK, et al. Sequencing of the alphasynuclein gene in a large series of case of familial Parkinson's disease fails to reveal any further mutations. Hum Mol Genet 1998; 7:751-753.

21. Lücking CB, Dürr A, Bonifati V, et al. Association between early-onset Parkinson's disease and mutations in the parkin gene. $\mathrm{N}$ Engl J Med 2000; 342:1560-1567. 